\title{
High turnover rates of copepod fecal pellets due to Noctiluca scintillans grazing
}

\author{
Thomas Kiørboe* \\ Danish Institute for Fisheries Research, Kavalergården 6, 2920 Charlottenlund, Denmark
}

\begin{abstract}
Copepod fecal pellet production and vertical flux, as well as vertical distributions of copepods, fecal pellets and the heterotrophic dinoflagellate Noctiluca scintillans were monitored in an upwelling plume off the coast of Brazil during $5 \mathrm{~d}$ in austral spring. Less than half (20 to $45 \%$ ) of the pellets produced in the overlying water column reached sediment traps positioned at 30 to $60 \mathrm{~m}$ depth, and specific sinking losses computed from steady-state considerations varied inversely with trap depth between 0.3 and $2.9 \mathrm{~d}^{-1}$. Total specific losses varied between 0.6 and $16 \mathrm{~d}^{-1}$, and the major part of these losses were thus unaccounted for by sinking and must have been due to remineralization in the water column; estimated specific remineralization rates increased with the ageing of the plume and varied between 0.3 and $13 \mathrm{~d}^{-1}$. N. scintillans occurred in increasing concentrations in the upwelling plume as the latter aged, up to $5 \times 10^{5}$ cells $\mathrm{m}^{-2}$, and fecal pellets occurred commonly in the food vacuoles of $N$. scintillans. Specific fecal pellet remineralization rates were linearly related to the abundance of $N$. scintillans. This relation can be quantitatively accounted for if $N$. scintillans clears the water for fecal pellets at about $0.6 \mathrm{l} \mathrm{cell}^{-1} \mathrm{~d}^{-1}$. A simple encounter model suggests that such high clearance rates are feasible. Since N. scintillans occurs at typical abundances of about $10^{6} \mathrm{cells} \mathrm{m}^{-2}$ in temperate seas during spring, summer and autumn, it may contribute significantly to the recycling of rapidly sinking fecal pellets in the water column.
\end{abstract}

KEY WORDS: Copepod fecal pellets $\cdot$ Turnover $\cdot$ Flux $\cdot$ Pellet grazing

\section{INTRODUCTION}

Copepod fecal pellets, once thought to be important vehicles for vertical organic matter transport, are now believed to often become remineralised in the upper ocean rather than sedimenting to the seafloor, even in shallow water (e.g. Smetacek 1980, Viitasalo et al. 1999). The evidence stems mainly from the scarcity of fecal pellets in sediment traps relative to the rate at which pellets are produced in the overlying water column (Turner 2002). Since fecal pellets sink rapidly $\left(\sim 100 \mathrm{~m} \mathrm{~d}^{-1}\right)$, their residence time in the surface layer is typically less than a day, and remineralization therefore must be rapid to significantly reduce sinking losses. A number of mechanisms for pellet degradation have been suggested, including leakage of solutes (Jumars et al. 1989, Urban-Rich 1999), solubilization by colonizing bacteria (Jacobsen \& Azam 1984, Hansen \&
Bech 1996), and metazoan coprorhexy and coprophageous feeding (Lampitt et al. 1991, Noji et al. 1991). Dense populations of flux feeding Oithona similis copepods, for example, may at times provide a very efficient 'coprophageous filter' that remineralizes most pellet material in the upper ocean (Gonzales \& Smetacek 1994).

Another likely important fecal pellet feeder is Noctiluca scintillans. This heterotrophic dinoflagellate is omnivorous and has been reported to feed on almost anything from small phytoplankton cells to aggregates and detrital particles, including fecal pellets (Enomoto 1956, Prasad 1958). N. scintillans encounters prey particles either by intercepting prey as it itself ascends in the water column (Kiørboe \& Titelman 1998), or by colonizing and feeding on diatom aggregates (Tiselius \& Kiørboe 1998). Solitary N. scintillans cells secrete $\mathrm{mm}$ - to $\mathrm{cm}$-long mucus threads on which prey particles 
are captured. These threads also facilitate the formation of mucoid feeding associations when cells are occurring at high concentrations (Omori \& Hamner 1982, Shanks \& Walters 1996). The long mucus threads and/or the mucoid feeding associations may also prove efficient in collecting fluxing particles, such as sinking copepod fecal pellets. Since N. scintillans may occur in very high concentrations, particularly during and in
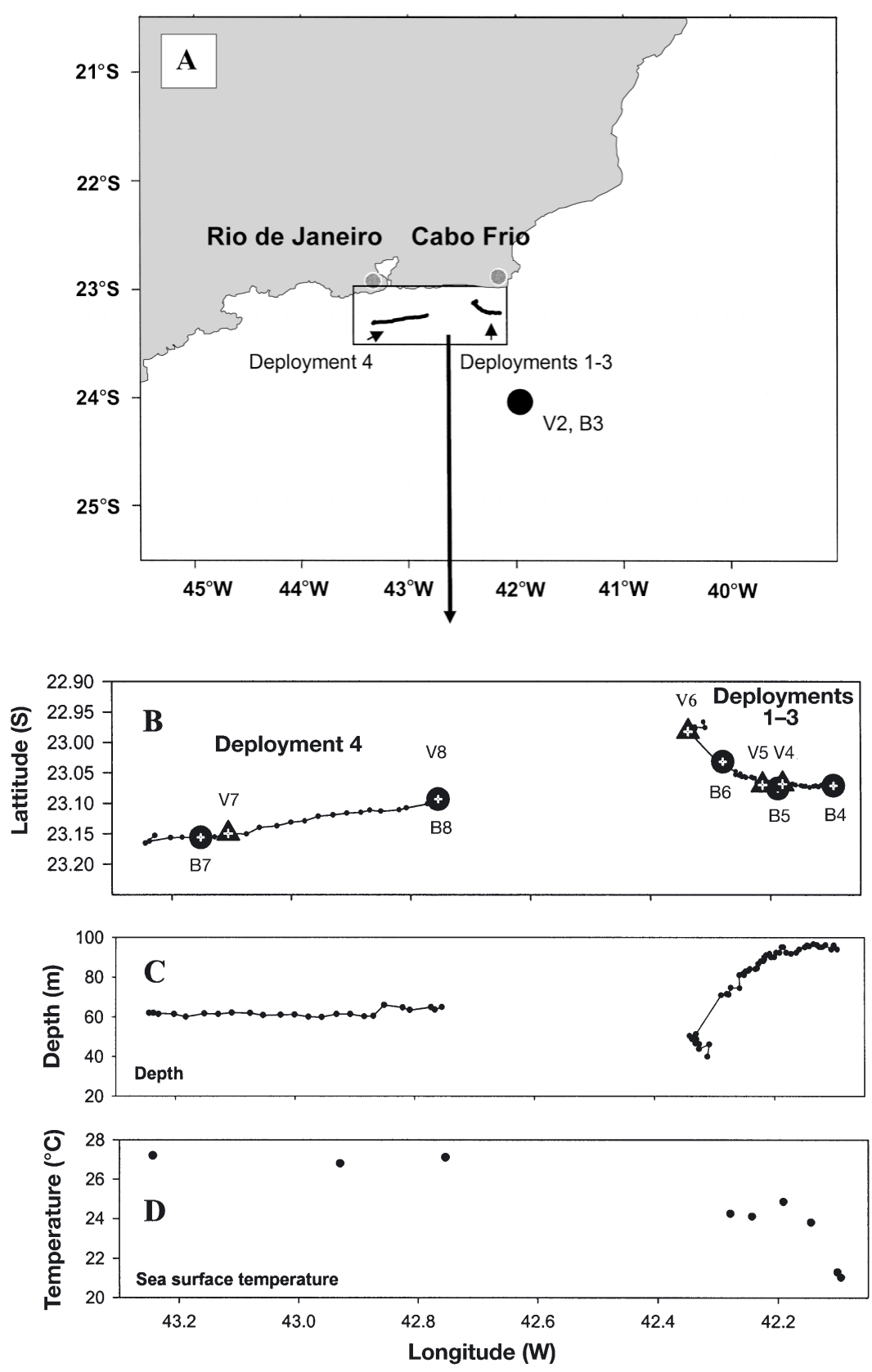

Fig. 1. (A) Map of study area, (B) buoy track and sampling stations, (C) water depth, and (D) sea surface temperature. Positions of buoy shown at $1 \mathrm{~h}$ intervals (small dots). Bottle profiles were taken at B-stations and video-profiles at $\mathrm{V}$-stations. Three trap deployments were made on the eastern buoy-track and one trap deployment on the western track the aftermath of diatom blooms (Kiørboe \& Titelman 1998, Dela-Cruz et al. 2002), it may potentially contribute significantly to the rapid turnover of sinking pellets in such environments.

Here I report on a study of copepod fecal pellet production, vertical flux, and turnover conducted in an upwelling plume in coastal waters off the Brazilian coast. Noctiluca scintillans occurred in increasing abundance in the ageing plume and I examine the hypothesis that $N$. scintillans contributes to the turnover of sinking copepod fecal pellets in the upper water column.

\section{MATERIALS AND METHODS}

The experiment was conducted in neritic waters off the coast of Brazil between Rio de Janeiro and Cabo Frio during January and February 2002 (Fig. 1). Sampling was conducted about once per day as we followed a drifting buoy equipped with a drogue at 10 to $20 \mathrm{~m}$ depth and sediment traps suspended at 10 and 30-60 m depth. An off-shore station (without trap deployment) was, in addition, sampled for comparison. The mooring was deployed between 31 January and 3 February and between 3 and 4 February at water depths between 40 and $90 \mathrm{~m}$ (Fig. 1). Sampling included CTD casts, and collection of water with 121 Niskin bottles from 5 depths between the surface and the deepest sediment trap. The water was sieved through $10 \mu \mathrm{m}$ mesh and the numbers of adult and copepodid copepods (not determined to species), Noctiluca scintillans, and copepod fecal pellets were counted. A subsample $(\mathrm{n}=30)$ of the fecal pellets was sized. Vertical profiles of $N$. scintillans and copepod abundances were also recorded by means of an in situ video camera as described by Tiselius \& Kiørboe (1998). The camera views a volume of either 24 or $0.42 \mathrm{ml}$ per frame. The higher magnification was used for enumeration of plankters, and about 6000 frames were analyzed per sampling depth. An in situ fluorometer was attached to the camera rig.

Fecal pellet fluxes were estimated by sediment traps. These were simple tubes, $7.2 \mathrm{~cm}$ inner diameter and $60 \mathrm{~cm}$ 
high, and were equipped with 7 baffle tubes in the upper $10 \mathrm{~cm}$ to reduce resuspension of trapped material. Trap tubes were filled with water from the deployment depth and were deployed during 4 periods of 17 to $23 \mathrm{~h}$ duration. A $60 \mathrm{~mm}$ diameter petri dish filled with an $8 \%$ polyacrylamide solution was positioned at the bottom of each trap to collect and preserve settled material (Lundsgaard 1995, Kiørboe et al. 1998). Copepod fecal pellets were counted in 50 to 100 fields, $3 \times$ $3 \mathrm{~mm}^{2}$, of each petri dish under a dissecting microscope corresponding to 100 to 200 pellets, and 30 pellets were sized.

To estimate water column fecal pellet production, copepod assemblages were incubated on deck, in darkness at sea surface temperature. Copepods and other zooplankton were collected at night by a vertical haul with a $200 \mu \mathrm{m}$ mesh size WP2 net (Tranter 1968) from the depth of the deepest trap to the surface. In each of the experiments varying fractions of the cod end contents were immediately diluted into 4 to 6 cylinders of 31 that had a bottom made of $300 \mu \mathrm{m}$ plankton net. The cylinders were submerged into 51 jars containing water collected over the copepod collection depth range. After $3 \mathrm{~h}$ of incubation, the entire contents of the jars were filtered through a $10 \mu \mathrm{m}$ plankton net, and copepods and fecal pellets were enumerated. Fecal pellet abundance was regressed on copepod abundance, and the slope represents an estimate of the per capita fecal pellet production over the duration of the incubation. One experiment was conducted for each of the 4 trap deployments.

Fecal pellet degradation rates were estimated from the observations by means of 2 simple models. The first model disregards vertical heterogeneity of fecal pellet concentration and degradation rate above the deepest trap:

\section{Model 1:}

$$
\frac{\mathrm{d} F}{\mathrm{~d} t}=p C-s F-r F=p C-(s+r) F
$$

where $F\left(\mathrm{~m}^{-2}\right)$ is the fecal pellet abundance integrated from the surface to the deepest sediment trap, $C\left(\mathrm{~m}^{-2}\right)$ is the abundance of copepods over the same depth interval, $p$ is the specific fecal pellet production rate (pellets copepod ${ }^{-1} \mathrm{~d}^{-1}$ ), and $s$ and $r$ the specific sinking loss and remineralization rates of fecal pellets $\left(\mathrm{d}^{-1}\right)$, respectively. I assume steady state, thus $\mathrm{d} F / \mathrm{d} t=0$, and:

$$
F=\frac{p C}{s+r} \Rightarrow r=\frac{p C-J}{F}
$$

where $J$ is the pellet flux at the deep trap, and the specific sinking loss is estimated as $s=J / F$.

The alternative formulation takes vertical heterogeneity in concentrations and degradation rates into account:
Model 2:

$$
\frac{\mathrm{d} F(z)}{\mathrm{d} z}=v \frac{\partial F(z)}{\partial z}+p C(z)-r(z) F(z)
$$

where $F(z)$ and $C(z)$ are the fecal pellet and copepod concentrations at depth $z, r(z)$ is the depth-specific pellet degradation rate, and $v$ is the fecal pellet sinking velocity [estimated for individual traps as $J(z) / F(z)$ and averaged over all traps]. At steady state:

$$
r(z)=\frac{v \frac{\partial F(z)}{\partial z}+p C(z)}{F(z)}
$$

The remineralization rate averaged over the water column to trap depth $(h)$ is then

$$
r=\frac{\int_{0}^{h} r(z) \mathrm{d} z}{h}
$$

\section{RESULTS}

\section{Distributions and abundances}

The upwelling center was off Cabo Frio near the initial deployment of the buoy, and sea surface temperature increased as the buoy drifted westwards and the plume aged (Fig. 1). Vertical profiles of in situ fluorescence revealed low chlorophyll concentrations at the off-shore station, but higher and rather similar concentrations and vertical distributions of chlorophyll at the coastal stations with a broad subsurface maximum between 25 and $50 \mathrm{~m}$ (Fig. 2). Bottle casts and in situ video-recordings yielded similar abundances and vertical profiles of copepods and Noctiluca scintillans (Fig. 3). Copepods were abundant in the upper $50 \mathrm{~m}$ at the coastal stations, with peak concentrations of 10 to 30 copepods $\mathrm{l}^{-1}$ at 15 to $30 \mathrm{~m}$ depth. Depth-integrated abundances were similar among coastal stations, but substantially less at the off-shore station (Table 1). The concentration of copepod fecal pellets generally increased with depth in the upper 30 to $50 \mathrm{~m}_{\text {; }}$ at the off-shore station that was sampled deeper, there was a pronounced decline at depths exceeding $50 \mathrm{~m}$. Fecal pellet abundances were substantially less at the 2 westernmost stations than at all other stations (Table 1, Fig. 3). N. scintillans were found on all stations, but only in substantial concentrations at the most westerly stations. There was a significant negative relation between the depthintegrated number of fecal pellets per copepod and the depth-integrated abundance of $N$. scintillans (Fig. 4), suggesting that $N$. scintillans play a role in turning over fecal material. 


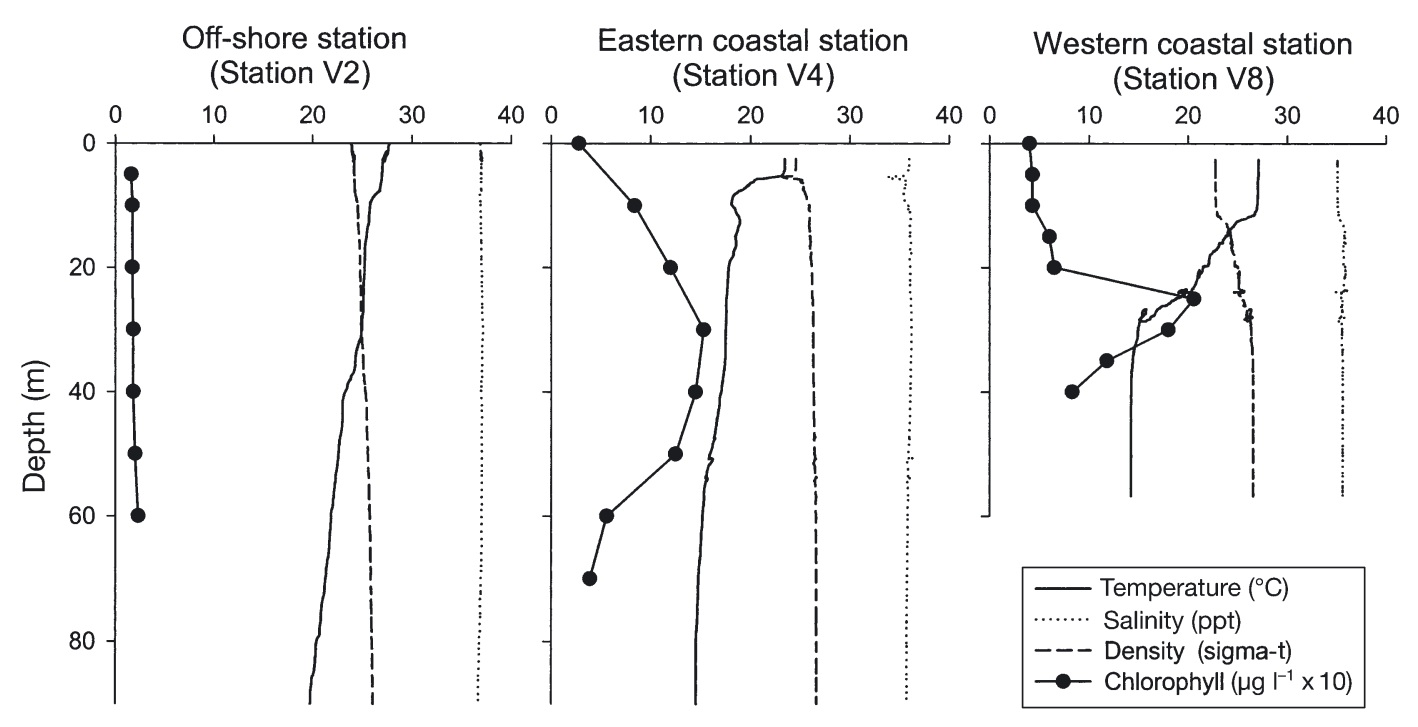

Fig. 2. CTD and fluorescence profiles at representative stations

\section{Fecal pellet production, flux, and degradation}

Per capita fecal pellet production rates $(p)$ were similar in all 4 experiments and averaged $3.3 \pm 0.4$ pellets copepod $^{-1} \mathrm{~d}^{-1}$ (Fig. 5). Fecal pellet fluxes $(J)$ were similar among experiments, between 3 and $5 \times 10^{5}$ pellets $\mathrm{m}^{-2} \mathrm{~d}^{-1}$, and constituted between 20 and $45 \%$ of the water column fecal pellet production rate $(p C)$, corresponding to specific sinking losses of 0.5 to $2.9 \mathrm{~d}^{-1}$ (Table 1). Thus, between 55 and $80 \%$ of the fecal pellets produced were degraded within the upper 30 to $60 \mathrm{~m}$. This leads to estimated specific pellet degradation rates by both approaches of between 1 and $13 \mathrm{~d}^{-1}$. Pellet degradation rate was linearly related to the average concentration of Noctiluca scintillans in the upper water column (Fig. 6a,b).
Sizes of fecal pellets produced in the incubations

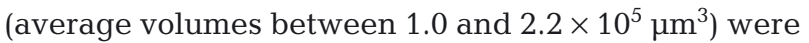
similar to those collected in the water column (averages between 1.0 and $1.5 \times 10^{5} \mu^{3}$ ), while pellets captured in the traps were slightly larger (averages between 1.8 and $2.7 \times 10^{5} \mu^{3}$ ).

\section{DISCUSSION}

Copepod fecal pellets are turned over rapidly in the upper ocean, both due to sinking losses and rapid remineralization. Here we found that turnover rate varied between 0.6 and $16 \mathrm{~d}^{-1}$, corresponding to average residence times of between 1.5 and $40 \mathrm{~h}$. During this time interval, the typical pellet has either left the upper

Table 1. Abundances of copepods and copepod fecal pellets, as well as estimates of flux, turnover, and specific sinking losses and degradation rates of copepod fecal pellets at 6 stations off the Brazilian coast. Station B3 was taken off-shore (Fig. 1) where no trap was deployed, whereas all other profiles were taken in neritic waters. Pellet production was computed applying an average production rate of 3.3 pellets copepod ${ }^{-1}$; this value may not be valid for the off-shore station but was used anyway, hence the parenthesis

\begin{tabular}{|c|c|c|c|c|c|c|}
\hline Station & B3 & B4 & B5 & B6 & B7 & B8 \\
\hline Trap deployment number & - & 1 & 1,2 & 3 & 4 & 4 \\
\hline Integration depth (h) (m) & 100 & 60 & 60 & 40 & 30 & 30 \\
\hline Copepod abundance $(C)$ (\# copepods $\mathrm{m}^{-2} \times 10^{3}$ ) & 150 & 647 & 340 & 373 & 610 & 337 \\
\hline Pellet production $(p C)$ (pellets $\left.\mathrm{m}^{-2} \mathrm{~d}^{-1} \times 10^{3}\right)$ & $(500)$ & 2130 & 1120 & 1230 & 2110 & 1110 \\
\hline Pellet flux $(\mathrm{J})$ (pellets $\mathrm{m}^{-2} \mathrm{~d}^{-1} \times 10^{3}$ ) & - & 440 & 400 & 360 & 480 & 480 \\
\hline Pellet abundance $(F)\left(\#\right.$ pellets $\left.\mathrm{m}^{-2} \times 10^{3}\right)$ & 831 & 745 & 601 & 639 & 127 & 160 \\
\hline Pellet turnover rate $(s+r)\left(\mathrm{d}^{-1}\right)$ & 0.6 & 2.9 & 1.9 & 1.9 & 15.9 & 7.0 \\
\hline Specific sinking loss $(s)\left(\mathrm{d}^{-1}\right)$ & $(0.3)^{\mathrm{a}}$ & 0.7 & 0.5 & 0.6 & 2.9 & 2.9 \\
\hline Specific degradation rate $(r)$ Model $1\left(\mathrm{~d}^{-1}\right)$ & $(03)$ & 2.2 & 1.4 & 1.3 & 13.0 & 4.1 \\
\hline Specific degradation rate $\left(\int r(z) \mathrm{d} z / h\right)$ Model $2\left(\mathrm{~d}^{-1}\right)$ & $(0.5)$ & 2.8 & 0.7 & 0.7 & 12.1 & 5.5 \\
\hline
\end{tabular}


mixed layer due to sinking, or it has been degraded. In the present study, degradation rates were either similar to (off-shore station) or higher to much higher than specific losses due to sinking. Thus, only a relatively small fraction of fecal pellets produced in the upper ocean leave the euphotic layer in the study area, a typical observation for both neritic and more oceanic regions of the ocean (Smetacek 1980, Viitasalo et al. 1999).

Our observations suggest that Noctiluca scintillans may be responsible for a significant fraction of the mineralization of fecal pellets, particularly in the westernmost and oldest part of the upwelling plume, where the dinoflagellate occurred in high concentrations. The slope of the linear relations between $N$. scintillans concentration and specific pellet degradation rate, $0.6 \mathrm{l} \mathrm{cell}^{-1} \mathrm{~d}^{-1}$ from both approaches, can be interpreted as the rate at which $N$. scintillans clears copepod fecal pellets. This appears to be a very high clearance rate for a small organism (the cells measure ca. 0.4 to $0.6 \mathrm{~mm}$ in diameter). For example, $N$. scintillans clears small phytoplankton cells at rates of up to a few ml per day (Kiørboe \& Titelman 1998). However, large $(\sim 0.5 \mathrm{~cm})$ neutrally buoyant diatom aggregates may be cleared at rates of about $0.6 \mathrm{l} \mathrm{d}^{-1}$ (Tiselius \& Kiørboe 1998). In these cases N. scintillans intercept prey particles as the cells ascend in the water. In the case of sinking fecal pellets, the encounters are, however, instead due to the sinking of the pellet, because pellet sinking velocity, averaging ca. $50 \mathrm{~m} \mathrm{~d}^{-1}$ in the present study (see legend of Table 1), exceeds the ascent rate of $N$. scintillans (about $20 \mathrm{~m} \mathrm{~d}^{-1}$, Kiørboe \& Titelman 1998). Because the smaller particle (the pellet) moves faster than the larger one (the $N$. scintillans cell), hydrodynamic effects can be ignored (cf. Kiørboe \& Titelman 1998), and the clearance rate $(\beta)$ can be estimated as:

$$
\beta=\pi R^{2} \Delta u
$$

where $R$ is the contact radius and $\Delta u$ the velocity difference. $N$. scintillans intercepts its prey by means of a long mucus thread that it produces. In situ video
Abundance, $\mathrm{H}^{-1}$
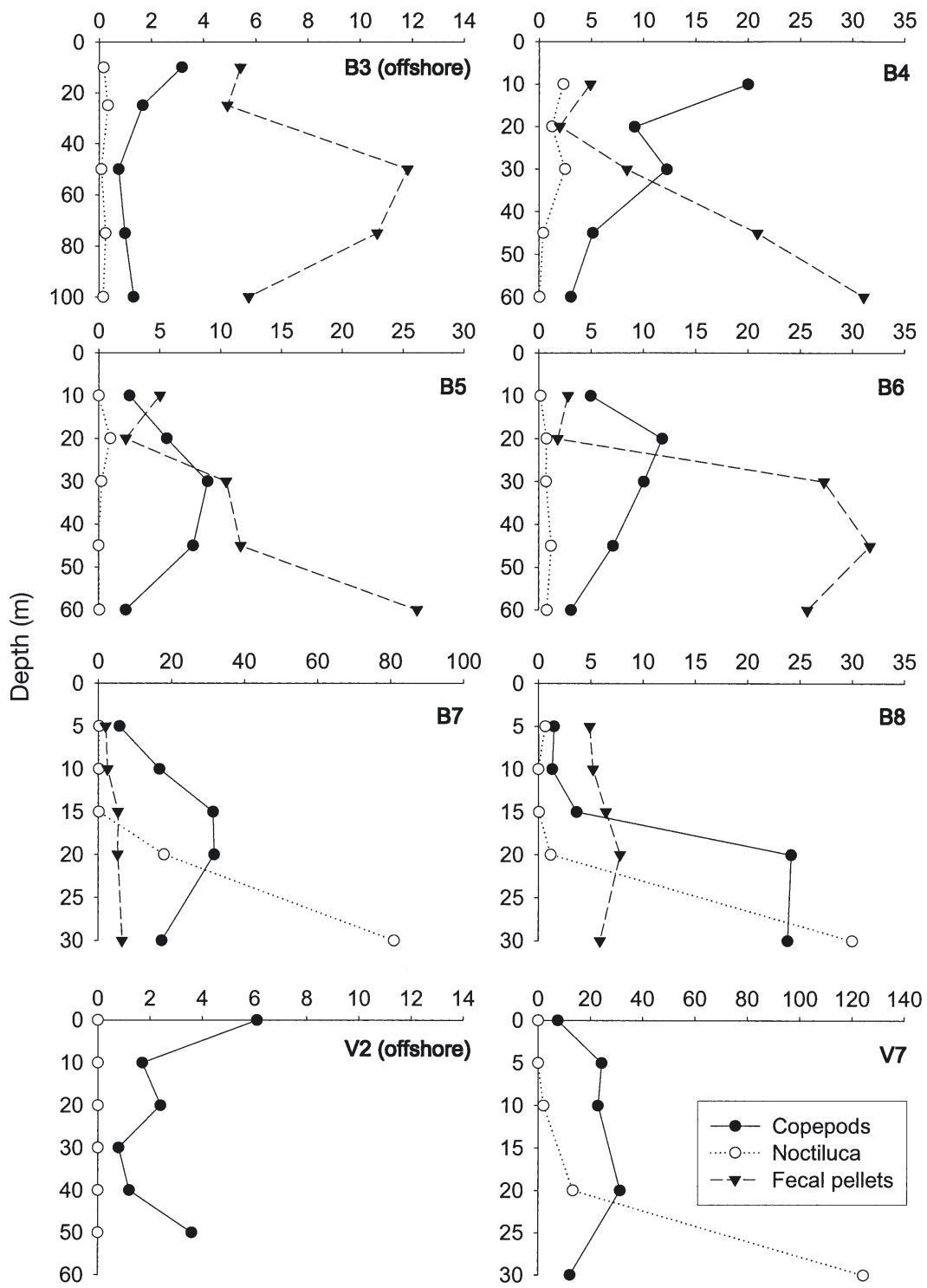

Fig. 3. Vertical concentration profiles of copepods, copepod fecal pellets, and Noctiluca scintillans. B3 to B8 are profiles obtained by bottle samples, V2 and V7 are profiles derived from in situ video recordings

recordings revealed the presence of such strings of up to several $\mathrm{cm}$ in length with food material attached. The nature of the food material could not be clearly identified on the video, but freshly caught cells had copepod fecal pellets in their food vacuoles. These mucus strings can be oriented in any direction from the cell (video observations) and enhance the size of the dining sphere of N. scintillans, although it is impossible to accurately estimate by how much. To account for the clearance rate estimated from Fig. $6\left(600 \mathrm{ml} \mathrm{d}^{-1}\right)$, given the velocity difference between cells and fecal pellets (pellet sinking velocity $+N$. scintillans ascent velocity $=72 \mathrm{~m} \mathrm{~d}^{-1}$ ), a contact radius of $1.6 \mathrm{~mm}$ is required. This estimate is 


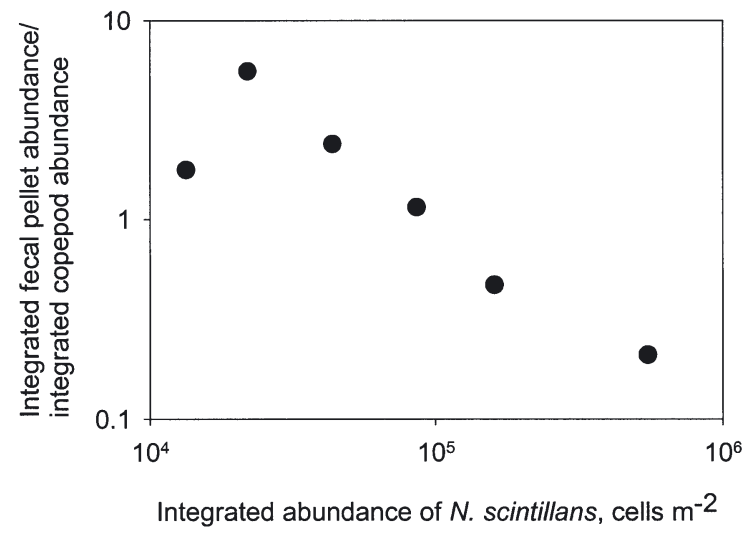

Fig. 4. Ratio of fecal pellet abundance to copepod abundance (both depth-integrated) as a function of depth-integrated abundance of Noctiluca scintillans

not inconsistent with the combined effect of cell size $(0.5 \mathrm{~mm})$, pellet size (average length $0.1 \mathrm{~mm}$ ) and mucus string length (1 to $20 \mathrm{~mm}$ ).

With a clearance rate of the estimated magnitude and water column peak fecal-pellet concentrations of 10 to $30 \mathrm{l}^{-1}$, this implies pellet ingestion rates of 6 to 18 pellets cell ${ }^{-1} \mathrm{~d}^{-1}$. With an average pellet volume of ca. $10^{5} \mu^{3}$, and assuming a pellet carbon content of
$10^{-7} \mu \mathrm{g} \mathrm{C} \mathrm{mm}^{-3}$ and a Noctiluca scintillans carbon content of $0.22 \mu \mathrm{g} \mathrm{C}$ cell $^{-1}$ (Kiørboe \& Titelman 1998), this corresponds to specific ingestion rates of 0.3 to $0.9 \mathrm{~d}^{-1}$. $N$. scintillans may grow at specific rates of up to $0.6 \mathrm{~d}^{-1}$ (Buskey 1995, Kiørboe \& Titelman 1998), and assuming a growth yield of $33 \%$ the above estimate thus suggests that $N$. scintillans may obtain a significant fraction of its nutrition from sinking fecal pellets.

Noctiluca scintillans is distributed globally. The presence of $N$. scintillans is often evident from dense aggregations of cells at the surface during summer and fall in temperate waters. During such red-tide blooms, surface concentrations may exceed $10^{4}$ to $10^{5}$ cells $1^{-1}$ (Schaumann et al. 1988, Huang \& Qi 1997), and subsurface concentrations of $10^{3}$ to $10^{4}$ cells $\mathrm{l}^{-1}$ with depthintegrated abundances in excess of $10^{7}$ cells $\mathrm{m}^{-2}$ have also occasionally been recorded (Huang \& Qi 1997, Kiørboe et al. 1998). Apart from such spectacular bloom events, the abundance of $N$. scintillans is rarely reported from monitoring studies since they are normally not quantified in zooplankton samples, and they are too rare to be quantified in typical phytoplankton samples. However, a few monitoring studies aimed specifically at $N$. scintillans suggest that the highest cell abundances reported in this study are quite typical during the summer half-year over the shelf of temperate waters. Thus, Uhlig \& Sahling (1990), Huang \& Qi (1997),
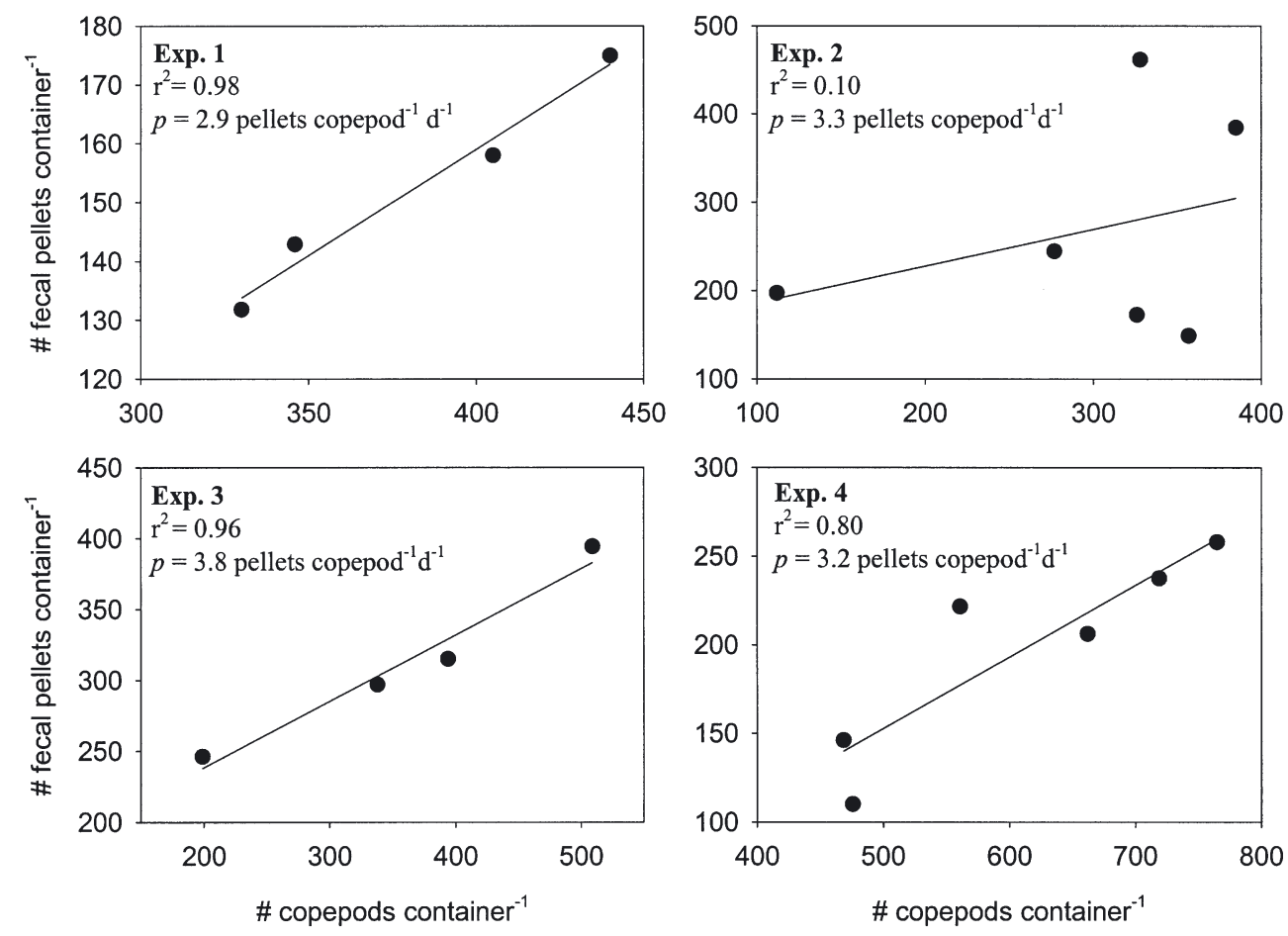

Fig. 5. Per capita fecal pellet production rate. Number of copepod fecal pellets per incubation container after 3 h of incubation as a function of the number of copepods per container in 4 experiments (one experiment per trap deployment). Estimates of daily per capita fecal pellet production rates $\left(p\right.$; fecal pellets copepod ${ }^{-1} \mathrm{~d}^{-1}$ ) have been shown for each experiment 

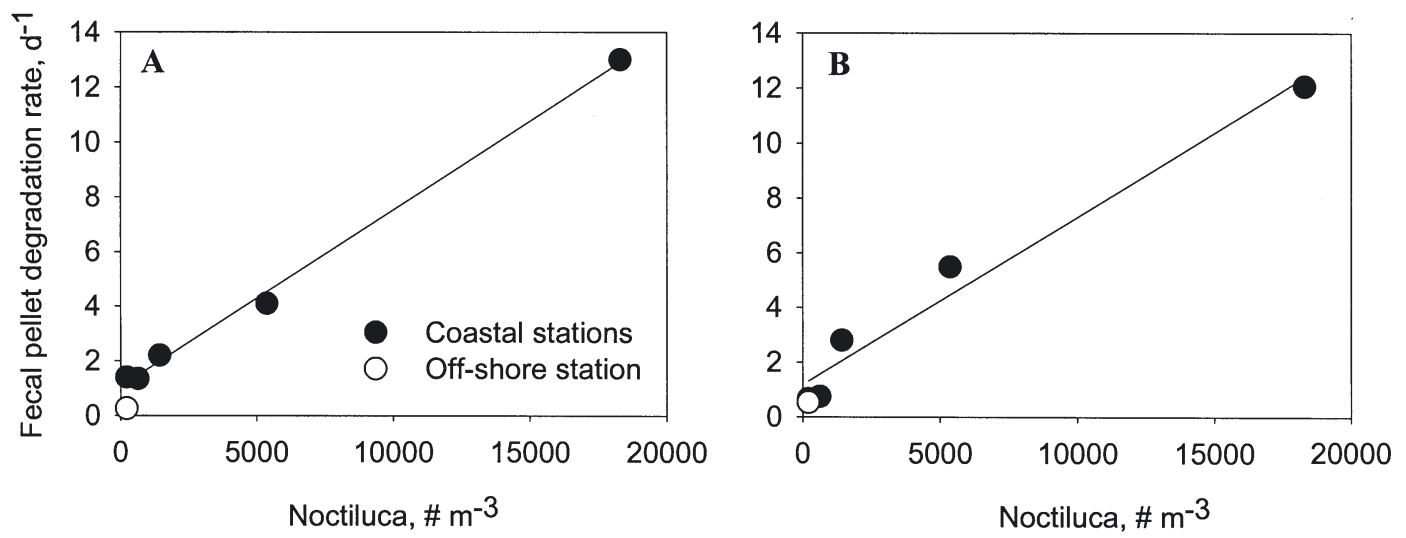

Fig. 6. Specific degradation rates of copepod fecal pellets $\left(r_{;} \mathrm{d}^{-1}\right)$ in the upper 30 to $60 \mathrm{~m}$ of the water column as a function of depth-averaged concentration of Noctiluca scintillans at 5 coastal stations ([N]; cells $\mathrm{m}^{-3}$ ) (@) estimated by Model 1 (A) and Model 2 (B). The regression lines have been shown. Model 1: $r=1.0+0.6 \times 10^{-3}[\mathrm{~N}]\left(\mathrm{R}^{2}=0.99\right) ;$ Model $2: r=1.2+0.6 \times 10^{-3}[\mathrm{~N}]$ $\left(R^{2}=0.97\right)$. (O) approximate value for the off-shore station, which has been computed assuming identical pellet sinking velocity and copepod fecal pellet production rate as for the coastal stations (not included in regressions)

Nakamura (1998), and Murray \& Suthers (1999) all found subsurface concentrations of 100 to 200 cells $^{-1}$ for extended periods (months) during spring, summer and/or fall in various shelf seas (North Sea, South China Sea, Seto Inland Sea, southeast Australian estuaries, respectively). These concentrations correspond to abundances of 2 to $10 \times 10^{6}$ cells m$^{-2}$ if integrated over a 20 to $50 \mathrm{~m}$ euphotic zone. Copepods are often ascribed the major role in rapidly turning over their own fecal pellets in the upper water column (Smetacek 1980, Lampitt et al. 1991). However, if the above densities of N. scintillans are representative of the summer plankton of temperate waters, $N$. scintillans may be equally or more important in preventing loss of fecal pellet material from surface waters and, thus, in sustaining plankton production throughout the summer half year.

Acknowledgements. I acknowledge the kind invitation of Prof. Dr. Rubens Lopes and Prof. Dr. Salvador A. Gaeta to participate in the 2002 summer cruise of the Brazilian DEPROAS project (Ecosystem Dynamics of the Continental Shelf Region of the Southwestern Atlantic, DEPROAS contract no. PRONEX-CNPq 66.2368/1996-7). I thank the captain and crew of RV 'Prof W. Besna', and the participating scientists and technicians for their help during the cruise, particularly Marcos Yoshinaga and Mayza Pompeu, Pernille Nielsen for counting the bottle samples, and Uffe Thygesen for help with model development. Financial support was received from the Danish National Science Research Council (21-010549) and the Danish Network for Fisheries and Aquaculture, financed by the Danish Ministry for Food, Agriculture, and Fisheries and the Danish Agricultural and Veterinary Research Council.

\section{LITERATURE CITED}

Buskey EJ (1995) Growth and bioluminiscence of Noctiluca scintillans on varying algal diets. J Plankton Res 17:29-40
Dela-Cruz J, Ajani P, Lee R, Pritchard T, Suthers I (2002) Temporal abundance patterns of the red tide dinoflagellate Noctiluca scintillans along the southeast coast of Australia. Mar Ecol Prog Ser 236:75-88

Enomoto Y (1956) On the occurrence and the food of Noctiluca scintillans (Macartney) in the waters adjacent to the west coast of Kyushu, with special reference to the possibility of the damage caused to fish eggs by that plankton. Bull Jpn Soc Fish 22:82-88

Gonzales HE, Smetacek V (1994) The possible role of the cyclopoid copepod Oithona in retarding vertical flux of zooplankton fecal material. Mar Ecol Prog Ser 113: 233-246

Hansen B, Bech G (1996) Bacteria associated with a marine planktonic copepod in culture. I. Bacterial genera in seawater, body surface, intestines and fecal pellets and succession during fecal pellet degradation. J Plankton Res 18: 257-273

Huang C, Qi Y (1997) The abundance cycle and influence factors on red tide phenomena of Noctiluca scintillans (Dinophyceae) in Dapeng Bay, the South China Sea. J Plankton Res 19:303-318

Jacobsen TR, Azam F (1984) Role of bacteria in copepod fecal pellet decomposition: colonization, growth rates and mineralization. Bull Mar Sci 35:495-502

Jumars PA, Penry DL, Baross JA, Perry MJ, Frost BW (1989) Closing the microbial loop: dissolved carbon pathway to heterotrophic bacteria from incomplete ingestion, digestion and absorption in animals. Deep-Sea Res 36:483-495

Kiørboe T, Titelman J (1998) Feeding, prey selection and prey encounter mechanisms in the heterotrophic dinoflagellate Noctiluca scintillans. J Plankton Res 20:1615-1636

Kiørboe T, Tiselius P, Michell-Innes B, Hansen JLS, Visser AW, Mari X (1998) Intensive aggregate formation with low vertical flux during an upwelling-induced diatom bloom. Limnol Oceanogr 43:104-116

Lampitt RS, Noji T, Bodungen BV (1991) What happens to zooplankton fecal pellets? Implications for material flux. Mar Biol 104:15-23

Lundsgaard C (1995) Use of high viscosity medium in studies of aggregates. In: Floderus S, Heiskanen AS, Olesen M, Wassmann P (eds) Sediment trap studies in Nordic countries. NurmitPrint, Nurmijävi, p 141-152 
Murray S, Suthers IM (1999) Population ecology of Noctiluca scintillans Macartney, a red-tide-forming dinoflagellate. Mar Freshw Res 50:243-252

Nakamura Y (1998) Biomass, feeding and production of Noctiluca scintillans in the Seto Inland Sea, Japan. J Plankton Res 20:2213-2222

Noji TT, Estep KW, MacIntyre F, Norbin F (1991) Image analysis of faecal material grazed upon by three species of copepods: evidence for coprorhexy, coprophagy and coprochaly. J Mar Biol Assoc UK 71:465-480

Omori M, Hamner WM (1982) Patchy distribution of zooplankton: behavior, population assessment and sampling problems. Mar Biol 72:193-200

Prasad R (1958) A note on the occurrence and feeding habits of Noctiluca and their effects on the plankton community and fisheries. Proc Indian Acad Sci Sect B 47:331-337

Schaumann K, Gerdes D, Hesse KJ (1988) Hydrographic and biological characteristics of a Noctiluca scintillans red tide in the German Bight, 1984. Meeresforschung 32:77-91

Shanks A, Walters K (1996) Feeding by the heterotrophic dinoflagellates (Noctiluca scintillans) in marine snow. Limnol Oceanogr 41:177-181

Editorial responsibility: Otto Kinne (Editor), Oldendorf/Luhe, Germany
Smetacek V (1980) Zooplankton standing stock, copepod faecal pellets and particulate detritus in Kiel Bight. Estuar Coast Mar Sci 11:477-490

Tiselius P, Kiørboe T (1998) Colonization of diatom aggregates by the dinoflagellate Noctiluca scintillans. Limnol Oceanogr 43:154-159

Tranter DJ (ed) (1968) Zooplankton sampling. Monographs on oceanographic methodology. UNESCO, Paris

Turner JT (2002) Zooplankton fecal pellets, marine snow and sinking phytoplankton blooms. Aquat Microb Ecol 27: 57-102

Uhlig G, Sahling G (1990) Long-term studies on Noctiluca scintillans in the German Bight. Population dynamics and red tide phenomena 1968-1988. Neth J Sea Res 25: 101-112

Urban-Rich J (1999) Release of dissolved organic carbon from copepod fecal pellets in the Greenland Sea. J Exp Mar Biol Ecol 232:107-124

Viitasalo M, Rosenberg M, Heiskanen AS, Koski M (1999) Sedimentation of copepod fecal material in the coastal northern Baltic Sea: where did all the pellets go? Limnol Oceanogr 44:1388-1399

Submitted: January 28, 2003; Accepted: April 9, 2003 Proofs received from author(s): July 28, 2003 